11. Шукис, Е. Р. Совершенствование сортового состава суданской травы в Алтайском крае / Е. Р. Шукис, С. К. Шукис. - Текст: непосредственный // Вестник Алтайского государственного аграрного университета. - 2017. - № 8 (154). - C. 23-27.

12. Шукис, С. К. Технологические и селекционные подходы к повышению урожайности и качества семян сорговых культур в Приобской лесостепи Алтайского края: автореферат диссертации на соискание ученой степени кандидата сельскохозяйственных наук: 06.01.05 / Шукис Станислав Константинович. - Барнаул, 2012. 19 с. - Текст: непосредственный.

13. Sidhu, M.C., Yill, Y.S. (1988). Effect of management factors on quality of sorghum. I. Res. 27-31.

\section{References}

1. Shatilov I.S. Sudanskaia trava / I.S. Shatilov, A.P. Movsisiants, I.A. Dranenko i dr. - Moskva: Kolos, 1981. - $205 \mathrm{~s}$.

2. Malinovskii B.N., Chernomordov V.F. Perspektivy vozdelyvaniia sorgo na Severnom Kavkaze // Voprosy biologii, selektsii i semenovodstva sorgo: Trudy Stavropolskogo NIISKh. - Stavropol, 1977. Vyp. 33. - S. 5.

3. Kashevarov N.I. Sudanka v kormoproizvodstve Sibiri / N.I. Kashevarov, R.I. Poliudina, N.V. Balykina i dr. - Novosibirsk, 2004. - 224 s.

4. Metodika polevykh opytov s kormovymi kulturami / A.S. Mitrofanov, G.D. Kharkov, M.N. Evdokimov i dr. // Vsesoiuznyi NII kormov. - Moskva, 1971 - $159 \mathrm{~s}$.
5. Metodika gosudarstvennogo sortoispytaniia selskokhoziaistvennykh kultur. - Moskva: Kolos, 1971. - $234 \mathrm{~s}$.

6. Metodicheskie ukazaniia po izucheniiu kollektsionnykh obraztsov kukuruzy, sorgo i krupianykh kultur. - Leningrad: VIR, 1968. - $51 \mathrm{~s}$.

7. Dospekhov B.A. Metodika polevogo opyta. Moskva: Kolos, 1979. - $336 \mathrm{~s}$

8. Volodin A.B. Potentsialnye vozmozhnosti sakharnogo sorgo / A.B. Volodin, M.P. Zhukova // Kormoproizvodstvo. - 2002. - No. 4. - S. 11-15.

9. Korobeinikov N.I. Sorgovye kultury / Programma raboty selektsentra ANIISKh do $2020 \mathrm{~g}$. I pod redaktsiei N.I. Korobeinikova. - Barnaul: GNU Altaiskii NIISKh, 2011. - S. 66-74.

10. Alabushev A.V. Sorgo (selektsiia, semenovodstvo, tekhnologii, ekonomika) / A.V. Alabushev, L.N. Antipenko, N.G. Gurskii i dr. - Rostov-naDonu: ZAO «Kniga», 2003. - $368 \mathrm{~s}$.

11. Shukis E.R., Shukis S.K. Sovershenstvovanie sortovogo sostava sudanskoi travy $v$ Altaiskom krae // Vestnik Altaiskogo gosudarstvennogo agrarnogo universiteta. - 2017. - No. 8 (154). S. 23-27.

12. Shukis S.K. Tekhnologicheskie i selektsionnye podkhody k povysheniiu urozhainosti i kachestva semian sorgovykh kultur $\mathrm{v}$ Priobskoi lesostepi Altaiskogo kraia / S.K. Shukis: avtoref. diss. k. s.-kh. nauk: 06.01.05. - Barnaul, 2012. $19 \mathrm{~s}$.

13. Sidhu, M.C., Yill, Y.S. (1988). Effect of management factors on quality of sorghum. I. Res. 27-31. В ЗАВИСИМОСТИ ОТ СОВМЕСТНОГО ВНЕСЕНИЯ АММОФОСА И АММИАЧНОЙ СЕЛИТРЫ

\title{
FORAGE PRODUCTIVITY AND QUALITY OF HAYFIELDS DEPENDING ON COMBINED APPLICATION OF AMMONIUM PHOSPHATE FERTILIZER AND AMMONIUM NITRATE FERTILIZER
}

Ключевые слова: естественные кормовые угодья, комплекснье минеральные удобрения, урожайность, сено, переваримый протеин.

Приводится действие комплексного удобрения и смеси простых минеральных удобрений на увеличение продуктивности и улучшение качества корма сенокос- ных угодий в условиях среднегорной зоны Республики Алтай. Для естественных кормовых угодий среднегорной зоны Республики Алтай характерно преобладание разнотравно-злакового типа растительности. Почвы имеют недостаточное количество доступного фосфора и повышенное содержание обменного калия, поэтому целесообразно внесение минеральных удобрений, со- 
держащих азот и фосфор. Исследования проводились в 2018-2020 гг. на базе КФК «Егармина М.М.» Шебалинского района Республики Алтай. По вариантам внесения аммофоса и его сочетания с аммиачной селитрой в дозах 20 и 40 кг/га действующего вещества получена прибавка урожайности 24,1-85,9\% (0,72 до 2,56 т/га). Действие минеральных удобрений проявляется не только в увеличении урожайности, но и в улучшении питательности и качества кормовой массы. Обеспеченность кормовой единицы переваримым протеином повысилась на 15-35 г, по сравнению с контролем. Максимальное значение данного показателя (116 г) отмечено на варианте $\mathrm{N}_{12} \mathrm{P}_{52}$. Таким образом, внесение минеральных удобрений позволило получить корм, удовлетворяющий требованиям зоотехнической нормы.

Keywords: natural forage lands, multiple-nutrient mineral fertilizers, yield, hay, digestible protein.

This paper discusses the effect of a multiple-nutrient fertilizer and a mixture of simple mineral fertilizers on yield

Басаргина Ольга Михайловна, н.с., Горно-Алтайский НИИ сельского хозяйства - филиал, ФГБНУ «Федеральный Алтайский научный центр агробиотехнологий», с. Майма, Республика Алтай, Российская Федерация, e-mail: olga.basargina.79@mail.ru. increase and forage quality improvement of hayfields under the conditions of the mid-mountain zone of the Republic of Altai. The natural forage lands of the mid-mountain zone of the Republic of Altai are characterized by the predominance of the motley grass-grasses type of vegetation. The soils are deficient in available phosphorus and have increased exchangeable potassium content, so it is advisable to apply mineral fertilizers containing nitrogen and phosphorus. The research was conducted from 2018 through 2020 on the farm of the KFK "Yegarmina M.M." in the Shebalinskiy District of the Republic of Altai. In the variants of ammonium phosphate fertilizer application and its combination with ammonium nitrate in the rates of 20 and $40 \mathrm{~kg}$ ha (primary nutrient basis), yield increase of 24.1$85.9 \%(0.72-2.56 \mathrm{t}$ ha) was obtained. The mineral fertilizers not only increase the yields, but also improve the nutritional value and forage quality. Digestible protein content in one fodder unit increased by $15-35 \mathrm{~g}$ as compared to that of the control. The maximum value of this indicator $(116 \mathrm{~g})$ was recorded in the variant with $\mathrm{N}_{12} \mathrm{P}_{52}$. Thus, the application of mineral fertilizers made it possible to obtain forages that met animal nutrition requirements.

Basargina Olga Mikhaylovna, Staff Scientist, GornoAltayskiy Research Institute of Agriculture, Branch, Federal Altai Scientific Center of Agro-Biotechnologies, Mayma, Republic of Altai, Russian Federation, e-mail: olga.basargina.79@mail.ru.

\section{Введение}

Естественные кормовые угодья Республики Алтай - основной источник получения полноценного корма для удовлетворения потребностей отрасли животноводства. Нерациональное использование сенокосов и пастбищ, а также снижение уровня минерального питания почв ведут к постепенной деградации природных лугOB.

Для основной массы сенокосов и пастбищ, отмечает В.Б. Троц, «...характерен весьма небогатый состав (злаки и разнотравье) растительного сообщества, с недобором бобовых видов и, как следствие, с несбалансированным по переваримому протеину кормом, получаемым с природных сенокосов. Продуктивность травостоев остается на невысоком уровне...» [1]. Диктуется необходимость в наиболее доступном приеме поверхностного улучшения луга - применении минеральных удобрений.

В связи с нерациональным и длительным периодом эксплуатации большего процента естественных кормовых угодий, ведущей к постепенному вырождению, регулярное внесение минеральных удобрений - необходимый фактор наращивания производства кормов и пролонга- ция продуктивного долгосрочного функционирования травостоев [2].

Разработки по данной тематике проводились и ранее, но использование аммофоса отдельно и совместно с аммиачной селитрой в них не предусматривалось, поэтому актуально обновление данных по действию комплексных минеральных удобрений на сенокосных угодьях в среднегорной зоне Республики Алтай.

Цель исследования - изучить повышение продуктивности и улучшение качества корма естественных кормовых угодий в результате поверхностного улучшения с использованием разных видов минеральных удобрений в условиях Шебалинского района среднегорной зоны Республики Алтай.

\section{Объекты и методы исследования}

Опытная работа была выполнена в условиях Шебалинского района Республики Алтай в 20182020 гг. на базе КФК «Егармина М.М.».

Почва опытного участка - чернозем горный среднемощный среднесуглинистый: содержание гумуса - 7,9\%, нейтральная реакция среды ( $\mathrm{pH}-6,13)$, низкое содержание $\mathrm{P}_{2} \mathrm{O}_{5}-53$ мг/кг почвы, высокое содержание $\mathrm{K}_{2} \mathrm{O}-148$ мг/кг поч- 
вы (по Чирикову), сумма поглощенных оснований - 51,44 мг-эКв/100 г почвы [3].

Опыт однофракторный, распределение делянок последовательное, в два яруса. Размер делянки $40 \mathrm{~m}^{2}$ в 4-кратной повторности. В опыте применялись минеральные удобрения: $\mathrm{N}_{60}$ аммиачная селитра (34\%), Р60 - двойной суперфоссфат (44\%), $\mathrm{N}_{12} \mathrm{P}_{52}$ - аммофрос (N - 12\%, P до 52\%). Контроль - природный неудобренный травостой. Удобрения распределялись поверхностно весной во время отрастания трав [4].

Закладка опыта, отбор проб, анализирование полученных данных были выполнены по общепринятым методикам [5, 6].

Погодные условия в период проведения исследований различались. Неравномерное распределение осадков за время вегетирования луговых трав сказалось на темпах роста, но в целом не оказало отрицательного воздействия на результатах опыта. Сумма температур выше $+10^{\circ} \mathrm{C}$ за вегетацию в 2018 г. составила $1483,3^{\circ} \mathrm{C}$, лето было теплым и влажным (июнь засушливый).

Начало вегетационного периода 2019 г. было теплым и достаточно увлажненным. Недостаток тепла и влаги - только в июле. Сумма положительных температур за вегетацию выше $+10^{\circ} \mathrm{C}$ составила $1451,9^{\circ} \mathrm{C}$.

Первая половина вегетационного периода 2020 г. была жаркая с большим недобором осадков. Июль с чрезмерно обильными осадками, особенно в первые 2 декады месяца. Сумма температур за вегетацию выше $+10^{\circ} \mathrm{C}$ составила $1822,3^{\circ} \mathrm{C}$.

Схема опыта представлена в таблице 1.

\section{Результаты исследований и их обсуждение}

Действие минеральных удобрений будет эфффективным при наличии нескольких фракторов, одним из которых является наличие в травостое ценных кормовых растений. При наличии таковых менее 20-25\% поверхностное улучшение проводить нецелесообразно.

В условиях проведения исследований (Шебалинская подзона среднегорной зоны Республики Алтай) распространены сенокосы с разнотравно-злаковым типом растительности. Доля бобовых растений составляет 3-5\%. Почва характеризуется содержанием недостаточного количества подвижного фосфора. Рационально будет активизировать повышение роста и развития злаковой группы сообщества, которая от- реагирует на внесение азотно-фросфорных удобрений [4].

В исследованиях Л.Ф. Трандышевой выявлено, что внесение минеральных удобрений является главным звеном улучшения природных пастбищ и сенокосов, где в первом минимуме находится азот. Использование фоссфорных удобрений - необходимый агротехнический прием при удобрении естественных лугов азотом [7].

В опыте продуктивность естественного сенокоса без применения удобрений за 2018-2020 гг. составила 2,98 т/га (табл. 1).

Внесение $\mathrm{N}_{60}$ и $\mathrm{P}_{60}$ в чистом виде обеспечило прибавку к контролю на 25,5-38,2\% (0,76-1,14 т/га), а совместно внесенные повысили урожайность сенокоса на $41,9 \%$, или на 1,25 т/га.

В вариантах действия сложного удобрения аммофоса $\left(\mathrm{N}_{12} \mathrm{P}_{52}\right)$ и 2 вариантов аммофоса, внесенного совместно с аммиачной селитрой $\left(\mathrm{N}_{12} \mathrm{P}_{52}+\mathrm{N}_{20}\right.$ и $\left.\mathrm{N}_{12} \mathrm{P}_{52}+\mathrm{N}_{40}\right)$, была обеспечена прибавка урожайности от 0,72 до 2,56 т/га, или $24,1-85,9 \%$. При совместно внесенных аммиачной селитры и двойного суперфосфата $\left(\mathrm{N}_{60} \mathrm{P}_{60}\right)$ прибавка к контролю больше, чем на варианте действия аммофоса $\left(\mathrm{N}_{12} \mathrm{P}_{52}\right)$, так как доза действующего вещества азота меньше в составе последнего.

Стоит заметить, что с увеличением дозы действующего вещества в вариантах увеличивается и прибавка урожайности. Основная доля участия в травостое лежит на злаковых растениях, которые и отзываются на внесение азота, а в связи с нехваткой доступного фоссрора в почве они положительно реагируют на действие aммофроса.

Максимальную прибавку урожайности сена обеспечило совместное внесение аммофоса с аммиачной селитрой: $\mathrm{N}_{12} \mathrm{P}_{52}+\mathrm{N}_{40}-2,56$ т/га, или $85,9 \%$ к контролю, где доза действующего вещества как азота, так и фосфора находилась на одном уровне.

Наряду с повышением продуктивности сенокосного угодья минеральные удобрения улучшают качество сена. Внесение азотсодержащих минеральных удобрений ведет к накоплению протеина в корме. Питательная ценность и химический состав корма изучены в фазу массового цветения травостоя. Среднее содержание переваримого протеина в корме колебалось от 40 до 76 г/кг (табл. 2). 
Таблица 1

Урожайность травостоя разнотравно-злакового сенокоса при действии минеральных удобрений, 2018-2020 г2.

\begin{tabular}{|c|c|c|c|c|c|c|}
\hline \multirow{2}{*}{ Вариант } & \multicolumn{3}{|c|}{ Урожайность сена, т/га } & \multicolumn{2}{c|}{ Прибавка урожая } \\
\cline { 2 - 7 } & 2018 г. & 2019 г. & 2020 г. & $\begin{array}{c}\text { среднее за } \\
2018-2020 \text { гг. }\end{array}$ & т/га & $\begin{array}{c}\text { в \% } \\
\text { к контролю }\end{array}$ \\
\hline Контроль & 2,48 & 3,78 & 2,70 & 2,98 & - & - \\
\hline $\mathrm{N}_{60}$ & 3,22 & 4,86 & 3,14 & 3,74 & 0,76 & 25,5 \\
\hline $\mathrm{P}_{60}$ & 2,86 & 5,22 & 4,30 & 4,12 & 1,14 & 38,2 \\
\hline $\mathrm{N}_{60} \mathrm{P}_{60}$ & 3,50 & 4,68 & 4,52 & 4,23 & 1,25 & 41,9 \\
\hline $\mathrm{N}_{12} \mathrm{P}_{52}$ & 3,86 & 3,50 & 3,74 & 3,70 & 0,72 & 24,1 \\
\hline $\mathrm{N}_{12} \mathrm{P}_{52}+\mathrm{N}_{20}$ & 3,82 & 5,34 & 4,74 & 4,63 & 1,65 & 55,3 \\
\hline $\mathrm{N}_{12} \mathrm{P}_{52}+\mathrm{N}_{40}$ & 4,96 & 6,16 & 5,52 & 5,54 & $\mathbf{2 , 5 6}$ & $\mathbf{8 5 , 9}$ \\
\hline $\mathrm{HCP}_{05} \mathbf{4}$ & $\mathbf{0 , 7 6}$ & $\mathbf{2 , 5}$ & $\mathbf{0 , 8}$ & & & \\
\hline
\end{tabular}

Таблица 2

Питательность и качество корма травостоя разнотравно-злакового сенокоса, 2018-2020 г2. (среднее)

\begin{tabular}{|c|c|c|c|c|c|c|c|}
\hline Вариант & 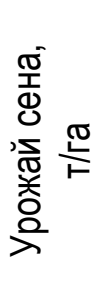 & 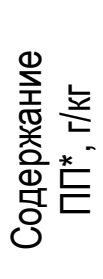 & 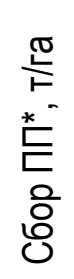 & 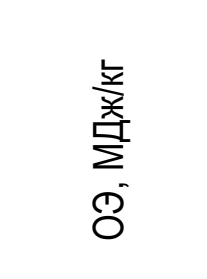 & 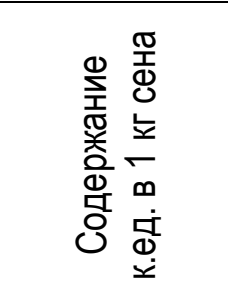 & 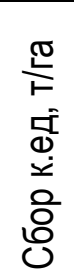 & 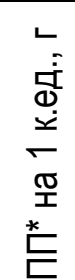 \\
\hline Контроль & 2,98 & 50 & 1,5 & 8,82 & 0,63 & 1,9 & 79 \\
\hline $\mathrm{N}_{60}$ & 3,74 & 40 & 1,5 & 8,49 & 0,58 & 2,1 & 71 \\
\hline$P_{60}$ & 4,12 & 61 & 2,5 & 8,79 & 0,63 & 2,6 & 96 \\
\hline $\mathrm{N}_{60} \mathrm{P}_{60}$ & 4,23 & 63 & 2,7 & 9,04 & 0,66 & 2,8 & 96 \\
\hline $\mathrm{N}_{12} \mathrm{P}_{52}$ & 3,70 & 76 & 2,8 & 9,00 & 0,66 & 2,4 & 116 \\
\hline $\mathrm{N}_{12} \mathrm{P}_{52}+\mathrm{N}_{20}$ & 4,63 & 67 & 3,1 & 9,21 & 0,69 & 3,1 & 100 \\
\hline $\mathrm{N}_{12} \mathrm{P}_{52}+\mathrm{N}_{40}$ & 5,54 & 45 & 2,5 & 8,63 & 0,60 & 3,3 & 76 \\
\hline $\begin{array}{c}\text { Зоотехнические } \\
\text { нормы }\end{array}$ & & & & 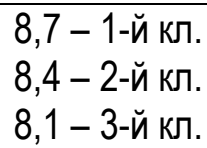 & $\begin{array}{l}0,61 \text { - 1-й кл. } \\
0,57 \text { - 2-й кл. } \\
0,53 \text { - 3-й кл. }\end{array}$ & & \\
\hline
\end{tabular}

Примечание. *ПП- переваримый протеин.

Действие минеральных удобрений способствовало росту сбора переваримого протеина и кормовых единиц. На вариантах действия удобрений $\mathrm{N}_{12} \mathrm{P}_{52}$ и $\mathrm{N}_{12} \mathrm{P}_{52}+\mathrm{N}_{20}$ отмечено максимальное увеличение сбора переваримого протеина от 2,8-3,1 т/га (против 1,5 т/га на контроле). Сбор кормовых единиц возрос на всех вариантах опыта и варьировал от 1,9 до 3,3 т/га.

Содержание кормовых единиц, обменная энергия на уровне контрольного варианта.

Действие минеральных удобрений благоприятно повлияло на показатель обеспеченности кормовой единицы переваримым протеином. Все варианты удобрений, кроме вариантов вне- сения азота отдельно и совместно внесенного с аммофосом в дозе $40 \mathrm{kr/га,} \mathrm{соответствуют} \mathrm{зо0-}$ технической норме. По сравнению с контролем обеспеченность повысилась на 15-35 г. Максимальное значение данного показателя (116 г) отмечено на варианте $\mathrm{N}_{12} \mathrm{P}_{52}$.

\section{Заключение}

При изучении результатов поверхностного улучшения сенокосов на основе действия минеральных удобрений, за трехлетний цикл исследований, выявлена положительная динамика повышения продуктивности и качества корма. 
В связи с преобладанием злаковых трав на естественных кормовых угодьях среднегорной зоны Республики Алтай с дефицитом в почвах азота и фосфора актуально внесение комплексных минеральных удобрений, в составе которых содержатся азот и фосфор. Использование аммофоса, содержащего фосфор в более растворимой форме, чем суперфосфрат, оказало большое влияние на формирование продуктивности.

Совместное внесение аммофоса и добавление 20 кг/га селитры обеспечивают рост продуктивности в 1,5 раза в сравнении с контролем.

Действие минеральных удобрений способствовало повышению питательности кормовой массы: обеспеченность кормовой единицы переваримым протеином при существенном повышении урожайности соответствовала зоотехническим нормам.

\section{Библиографический список}

1. Троц, В. Б. Агробиологические основы формирования высокобелковых травостоев кормовых культур в лесостепи Среднего Поволжья: авторесрерат диссертации на соискание ученой степени доктора сельскохозяйственных наук: 06.01.09 / Троц Василий Борисович. - Кинель. 2008. - 38 с. - Текст: непосредственный.

2. Кашеваров, Н. И. Достижения и перспективы развития кормопроизводства в Западной Сибири / Н. И. Кашеваров, В. П. Данилов. - Текст: непосредственный // Достижения науки техники АПК. - 2006. - № 1. - С. 19-22.

3. Агрохимическая характеристика сельскохозяйственных угодий Республики Алтай (19722009 гг.): пособие / МСХ РФ ФГУ САС «ГорноАлтайская». - Горно-Алтайск: ОАО «ГорноАлтайская типография», 2010. - 63 с. - Текст: непосредственный.

4. Басаргина, О. М. Увеличение продуктивности сенокосов в условиях Шебалинского района Республики Алтай в связи с применением комплексных азотных удобрений / О.М.Басаргина. - Текст: непосредственный // Вестник Алтайского государственного аграрного университета. 2020. - № 3 (185). - С. 5-10.

5. Методика опытов на сенокосах и пастбищах / ВНИИК им. В. Р. Вильямса. - Москва: Агропромиздат, 1971. - 232 с. - Текст: непосредственный.
6. Доспехов, В. А. Методика полевого опыта / В. А. Доспехов. - Москва: Колос, 1985. - 336 с. Текст: непосредственный.

7. Трандышева, Л. Ф. Повышение продуктивности природных пастбищ низкогорий Горного Алтая / Л. Ф. Трандышева. - Текст: непосредственный // Интенсификация кормопроизводства и кормления животных на Алтае. - Новосибирск, 1987. - C. 21-28.

\section{References}

1. Trots, V.B. Agrobiologicheskie osnovy formirovaniia vysokobelkovykh travostoev kormovykh kultur v lesostepi Srednego Povolzhia: avtoref. diss. d-ra s.-kh. nauk: 06.01.09 / Trots Vasilii Borisovich. - Kinel, 2008. - 38 s.

2. Kashevarov, N.I. Dostizheniia i perspektivy razvitiia kormoproizvodstva $\mathrm{v}$ Zapadnoi Sibiri / N.I. Kashevarov, V.P. Danilov. - Tekst: neposredstvennyi // Dostizheniia nauki tekhniki APK. 2006. - No. 1. - S. 19-22.

3. Agrokhimicheskaia kharakteristika selskokhoziaistvennykh ugodii Respubliki Altai (19722009 gg.): posobie / MSKh RF FGU SAS «GornoAltaiskaia». - Gorno-Altaisk: OAO «GornoAltaiskaia tipografiia», 2010. - 63 s. - Tekst: neposredstvennyi.

4. Basargina, O.M. Uvelichenie produktivnosti senokosov $\mathrm{V}$ usloviiakh Shebalinskogo raiona Respubliki Altai $\mathrm{v}$ sviazi $\mathrm{s}$ primeneniem kompleksnykh azotnykh udobrenii / O.M. Basargina. Tekst: neposredstvennyi // Vestnik Altaiskogo gosudarstvennogo agrarnogo universiteta. - 2020. - No. 3 (185). - S. 5-10.

5. Metodika opytov na senokosakh i pastbishchakh / VNIIK im. V.R. Viliamsa. - Moskva: Agropromizdat, 1971. - 232 s. - Tekst: neposredstvennyi.

6. Dospekhov, V.A. Metodika polevogo opyta / V.A. Dospekhov. - Moskva: Kolos, 1985. - 336 s. Tekst: neposredstvennyi.

7. Trandysheva, L.F. Povyshenie produktivnosti prirodnykh pastbishch nizkogorii Gornogo Altaia / L.F. Trandysheva. - Tekst: neposredstvennyi // Intensifikatsiia kormoproizvodstva i kormleniia zhivotnykh na Altae. - Novosibirsk, 1987. S. 21-28.

Работа выполнена в рамках государственного задания ФГБНУ ФАНЦА № АAАA-A19119092490021-6. 